\title{
Planning for an ageing population
}

\author{
Rose Gilroy* \\ University of Newcastle
}

We live in an ageing society and each of us will grow old, if we are lucky. Analysis of voting patterns suggests that older people are more likely to cast their vote so this might seem like a double imperative to improve quality of life in later life.

This review explores five major issues:

- How can older people make ends meet with dignity?

- How can we improve the housing conditions of older people?

- How do we get a better health deal?

- What answers, if any, are there to the social care crisis?

- How can the new public health issue of loneliness and social isolation be addressed?

\section{Making ends meet}

Poverty has increased among older people in the UK to number some 2 million. Labour, Conservative and the Liberal Democrats all pledge to retain the triple lock guarantee for retirement pensions while the Labour party and the Conservatives also state they will retain the payment of Winter Fuel Allowance and retain the free bus pass. Both parties also pledge free TV licences with the Conservatives stating it is the responsibility of the $\mathrm{BBC}$ to pay for this. For many lonely older people, television is a major support and for this reason alone needs to be met in some way by society.

The Green party takes a different approach to income by maintaining its long-held pledge to a Universal Basic Income that will give every adult $£ 89$ per week but for a retired person this would be $£ 178$. This higher income would allow older people the dignity of paying their own way. A significant part of the rise in poverty has been due to the government-imposed rise in the State Pension age for women which is addressed by two of the parties. The Liberal Democrats and Labour talk of proper compensation while the latter also pledges to leave the pension age at 66 and to review this for those engaged in arduous work. Labour also pledge to end the digital barrier imposed on those applying for benefits by offering greater phone support, face to face and outreach support. Labour will also halt bank closures and end ATM charges allowing older people who may use more traditional money management methods easier access to banking services.

The ability to manage financially is not just a matter of income. There is major party consensus on the commitment to invest in energy efficiency no doubt driven by climate emergency but with implications for those living with the misery of fuel poverty. Labour pledge to upgrade the UK housing stock to reduce the average household energy bill by 
more than $£ 400$ by 2030 . The Conservatives plan to invest $£ 9.2$ Billion in energy efficiency across the residential, education and health sectors while the Greens, not surprisingly have several policies intending to improve insulation of every home with priority to low income households. New homes will be built to Passivhaus standard, a commitment also made by the Liberal Democrats who will offer free energy retrofits for low income households and incentivise improvements in the owner-occupied sector by reducing VAT at on home insulation and graduating stamp duty making efficient properties more attractive to purchasers.

\section{Improving housing conditions}

Poor housing that is damp, cold or downright dangerous creates not only miserable conditions for more than a million older households but also is felt in the NHS where 2015 research estimated the annual cost at $£ 1.4$ billion annually (Nicol et al, 2015). Tackling both cold homes and fuel poverty is a major priority as is building to higher standards though parties are vague on the details. The Conservatives pledge to "encourage innovative design and technology to make housing more affordable, accessible and suitable for disabled people and an ageing population." Given that most older people live in mainstream housing and plan to remain there this commitment to better space standards is one of the most significant steps that a government might take. The Greens also pledge to increase the number of dwellings built to mobility standards. All parties might benefit from reading Ben Glover's report Future Homes published in 2019 by Demos that called for housing that might meet the challenges of our society by being age proofed; suitable for multi-generational living and allowing space for home working. None of this seems to have found its way into the political parties housing ambitions.

The commitment to end no fault evictions is widely and rightly supported. Labour, the Greens and the Liberal Democrats all plan to massively increase the number of homes built with emphasis on social housing. While this is laudable there are significant barriers to be addressed: the ageing of the building workforce, the heavy reliance on East Europeans made worrying by Brexit uncertainties (this ruled out by the Lib Dems of course) and the skill shortage. The future may lie in off-site modular construction, but we seem far away from mainstreaming these methods.

\section{Getting a better health deal}

Investments in better housing standards and more energy efficient housing will benefit older people's health. In the NHS itself all parties pledge further investment while the Conservatives, somewhat wildly, will make funding a cure for dementia a collective priority. The Conservatives and the Liberal Democrats discuss social prescribing and the hospice movement, with the Conservatives pledging a cash injection of $£ 25$ million in August 2020 to support 200,000 at the end of their life, while the Liberal Democrats will move to free end of life care wherever a person chooses to be.

\section{Social Care}

The crisis in the NHS is caused in large part by the failure of successive governments to adequately deal with social care. Spending by government on social care for older people fell significantly from 2010 with self-funders in care homes paying significantly 
more than someone whose care is met by their local authority; 1.5 million older people with some unmet care needs and more than 100,000 vacancies in the care workforce. The Liberal Democrats aim to pool budgets for the NHS, Social Care and Public Health to support integrated care systems. Labour pledge to introduce the "Scottish system" under which personal care is free. They also commit to extend the eligibility criteria to ensure services for everyone including those with complex needs including dementia and to (at least) double the numbers receiving publicly funded care. The Conservatives state that no one will have to sell their home to pay for care but are vague on details of how this will be avoided. The Liberal Democrats pledge to create career pathways for care workers, an important step in transforming their low status and low pay.

The huge contribution of family and friends to elder care is widely acknowledged and rewarded. The Conservatives, with the poorest investment, will extend entitlement to leave to one week. Whether this is per year is left uncertain. Given the volatile demands care might make, one week seems somewhat derisory. The Greens with their Universal Basic Income state that they will continue to pay the full Carers Allowance of $£ 3,200$ to which that person can add the $£ 4,630$ UBI. Labour will increase the Carers Allowance for unpaid full-time carers while the Liberal Democrats will raise the earnings limit for working carers, give a statutory guarantee of repots breaks and provide a package of carer benefits.

On the social care issue all parties apart from the Conservatives make pledges that are in line with the demands of the major charities and campaigning groups suggesting that significant change is within reach.

\section{Addressing social isolation}

There is no magic bullet here but all parties pledge to extend transport networks particularly in rural areas improving infrequent or non-existent services. Revival of the high street concerns both Labour and Conservatives with the latter pledging a Towns Fund and all reviewing business rates for small businesses to halt closure of shops and everyday services. Reinvestment in the services that were so important to many older people - the library, the community centres etc., seems sadly lacking in all the manifestoes. Labour will invest in the public realm to promote safety of vulnerable road users and they, together with the Greens and the Liberal Democrats, aim to deliver healthier places by promoting walkable and cycle friendly places that create sociability. The possibility of being part of virtual communities is addressed by Labour's commitment to deliver free full fibre broadband to all by 2030 while the Conservatives aim for Gigabit broadband by 2025 . Access to the internet is rising including among the older generations however for many the issues are not simply cost but confidence and fear of being a victim of fraud. An investment in training and support would be welcome here.

In all these five significant areas there are party commitments that will go some way to delivering a better quality of life for older people by addressing social justice issues. The extent to which these are delivered and how accountable we can make the winning party remains to be seen.

* Correspondence address: Rose Gilroy, School of Architecture, Planning and Landscape, Claremont Tower, Newcastle University, Newcastle upon Tyne, NE1 7RU. Email: r.c.gilroy@newcastle.ac.uk 
p. 70. Planning for an ageing population

\section{References}

Nicol, S., Roys, M. and Garrett, H. (2015) The cost of poor housing to the NHS. Building and Research Establishment. 